\title{
Psychoses Chronic Delusional: Brief considerations
}

\author{
Ronaldo Chicre Araújo*1, José Dionísio de Paula Júnior ${ }^{1}$ and Gabriel da Costa Duriguetto ${ }^{1}$ \\ ${ }^{1}$ Department of Psychology, Foundation President Antônio Carlos (FUPAC), Brazil
}

Received: June 11, 2018; Published: June 18, 2018

*Corresponding author: Ronaldo Chicre Araujo, Department of Psychology, Foundation President Antônio Carlos (FUPAC), Rua Lincoln Rodrigues Costa, № 165 . Brazi

\begin{abstract}
Mini Review
The group of chronic delusional psychosis systematized had multiple elaborations raised by the French and German psychiatry nineteenth and early twentieth century. Psychoses are characterized by permanent delusions. Are considered delusions not only the beliefs and conceptions by which express the themes of delirious fiction, namely persecution, grandeur, jealousy but also ideoafetivos phenomena in which the delirium takes body as intuitions, illusions, interpretations, hallucinations, imaginative and passionate exaltation. These delusions cannot be conceived as simple errors in judgment [1]. In nosography Kraepelin and later with the works of Bleuler, many of these delusions became part of schizophrenia. Meanwhile, France has remained true to the description of chronic delusions outside the group of schizophrenia. The diagnostic and therapeutic point of view, it is important to resume the classification of chronic delusional psychotic disorders proposed by the French nosography.
\end{abstract}

She has chronic delusional psychosis without evolution deficit in the frames of systematized delusional psychosis (paranoia), and an increase in deficit in schizophrenia. This work will be limited to address the chronic systematized delusions that develop progressively without compromising the individual's adaptation capabilities.The chronic systematized delusions, also called paranoid psychoses are generally well organized, with rich and consistent stories. They maintain over time its contents and the richness of detail [2]. These delusions are linked to the construction of the personality of the delusional and develop with consistency and clarity second Kraepelin. They are characterized by a logical construction from false elements, which are the Clérambault postulates of delirious fable. Its evolution is insidious and progressive. Symptoms of these delusions, ie, interpretations, delusional perceptions, hallu cinatory activities, fables, are reducible to pathological beliefs. For consistent, due to its systematic, these delusions are presented to those who are close to the delirious often as plausible. It follows its power of conviction that can cause third parties to engage actively in the delirium, the title of induced delusional [3].

In the group of systematic chronic delusions are the passion and delusional delusions. Claiming it is procedural plaintiffs who go to justice because they have the conviction that were injured, they feel betrayed and wronged, and can reach the crime against their enemies; the inventors convinced that someone stole an idea; of passionate idealists who can commit violent acts in defense of what they think is the cause. The passionate delirium is delirium of jealousy, in which the individual is convinced of being betrayed in loving relationships; and erotomanic delirium, in which the individual is convinced of being loved by someone. In this delirium three phases succeed in evolution, namely a stage of hope, Therefore, while the current trend is to regroup all the psychoses under the term schizophrenia, clinical psychoses, far from being a uniform set, can be presented in different modalities. Clinical chronic delusional psychosis shows that a differentiated observation of psychotic patients is fundamental in terms of understanding diagnostic and therapeutic approach

\section{References}

1. Bernard, P Brisset C (1985) Psychiatry Manual. Sao Paulo: Masson.

2. Dalgalarrondo P (2000) Psychopathology and Symptomatology of mental disorders. Porto Alegre: Medical Arts 2: 15-25.

3. Clerambault G (1942) Les psychoses passionnelles. Oeuvres, Presses Universitaires de France, Paris, France. 
(C) This work is licensed under Creative Submission Link: https://biomedres.us/submit-manuscript.php

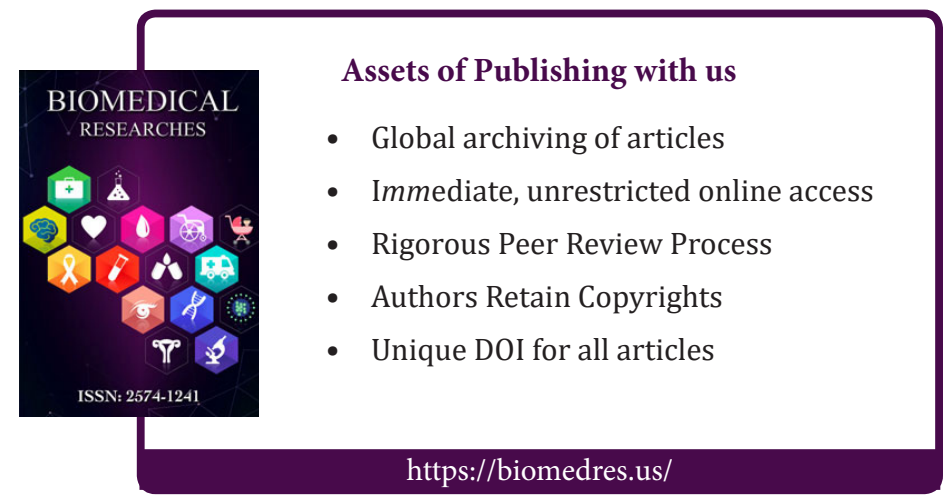

